\title{
The Kindergarten Readiness of Children Playgroup Based on Model of Learning Center
}

\author{
Maria Hidayanti \\ University of Majalengka, Jawa Barat, Indonesia \\ mariahidayanti247@yahoo.com
}

\begin{abstract}
This study aims to determine the kindergarten of children Playgroup based on model of learning centers and how the stimulation that is provided by teachers when learning activities. The research was conducted in the plygroup Bunda Balita class of 15 children. This study uses qualitative research methods are manifold phenomenology. Analysis of data using the model of Miles and Huberman step as for step (1) Reduction data (2) The presentation of data, (3) Drawing conclusion/verification. Data collected by observation, interview and use NST assay to measure the school readiness of children. The resulst of this study showed the playgroup. The stimulation provided by the teacher from the morning until noon through habituation activities, axemplary and stimulation when learning with questioning methods, storytelling, free play and play at the center, singing and practice. This study is find things that can better support the methods and provides the tools to play a more varied again, the need to enhance the creativity of teachers in creating other types of play activities.
\end{abstract}

Keywords : kindergarten; playgroup; learning center

\section{Introduction}

Every human being has various basic potentials that have been carried out since birth. Therefore the totality of its potential human beings are able to do all activities in an effort to maintain their survival. The human potential brought since birth must be developed to the maximum extent. These developments are carried out through education. Education is the right of every human being, this is confirmed in the 1945 Constitution Article 31 which contains "every citizen has the right to receive education". In essence, education is one of the main needs in human life. How human quality is greatly influenced by the education it has received. Which will have an impact on the development and progress of a nation. One of them is Indonesia as a developing country that will need an optimal contribution from Indonesian citizens.

Biecher and Snowman says that preschoolers are children aged 3-6 years. The Indonesian government stipulates that TK and RA children are children in the age range of 4 years to 6 years. Based on this age physical, social, emotional and cognitive characteristics can be recognized.

Besides that, there are 2 (two) important things that children need to have to enter TK, including:

1) Self help ability

That is the child's maturity to be able to communicate their needs. For example: children can say, "Teacher, I want to pee" do not let the child constantly wet the bed because they do not dare to state their needs.

2) Social help

That is the child's maturity to understand the needs of others. "Usually pre-school age children are still ego-centric, self-thinking continues. If the item is taken by a friend, he yells, etc., if he understands the needs of others, he will not behave like this,

In order for children to be more ready to enter new schools, we as parents / teachers must;

- Children are given fun information, about kindergarten as the initial perception about school. For example: having new friends, new toys, and also new and friendly teachers. 
- On the other hand parents must explain the consequences, for example playing with friends, then he must be willing to take turns and besides that must also be obedient to the teacher and rules or school rules.

- Explain why he must enter kindergarten, what is the purpose and what will be obtained in kindergarten, and by attending kindergarten children will have many friends and learn a lot when playing.

- So that children can understand what is concrete in the future when he sits in kindergarten by doing role playing, for example; mother becomes a teacher and child becomes a student or vice versa, even if it is possible to play that role the place and atmosphere are arranged in such a way as in a real kindergarten.

- In addition, mothers provide games that are often taught in kindergarten, in this way we have mentally prepared children to be ready for Kindergarten (TK) education.

- It is better for parents to start preparing a picture in advance before their children are ready to enter the TK, for example, they should be able to persuade their children to be able to enter their new school.

Following are the physical, social, emotional, and cognitive characteristics of children according to Biechler and Snowman:

1. Physical Characteristics

a. Very active.

b. Do a lot of activities.

c. Big muscles (arms, legs) first develop from smaller muscles (fingers).

d. The coordination of hands, feet and eyes is not perfect.

e. The body is flexible so it is easy to move.

f. Boys are generally bigger than girls.

2. Social characteristics

a. Friendly only to one or two people and easy to change.

b. Play in small groups.

c. Younger children play next to older children.

d. Play patterns vary according to social class and gender.

e. Disputes often occur and are easy to return to.

f. Has realized the role of sex.

3. Emotional characteristics

a. Expressing his emotions freely and openly. Angry attitude is more often shown.

b. Envy the hearts of other children. Always fighting for the attention of the deawasa near him (his teacher).

4. Cognitive characteristics

a. Generally skilled in language.

b. Has the desire to know the big one.

c. Expressing thoughts openly and spontaneously.

Kindergarten is a form of educational unit for early childhood on formal education pathways that organizes educational programs for children aged 4-6 years. Saasaran, kindergarten education is children aged 4-6 years, divided into two study groups based on age, namely Group A for children aged 4-5 years and group B for students aged 5-6 years. TK is held at least 6 days in a week with minimum service hours of 2.5 hours per day. The number of services in one year is at least 160 days or 34 weeks.

The transition condition from playing groups to childhood is one of the phases that is not easy, this is a big step for children, because in the nursery it is not the same as playing in groups. 
Children will be asked to be more independent. Based on the results of interviews with kindergarten teachers in Kertajati which states that children who enter the play group will first be seen from controlling the social emotional aspects of their environment and will better understand the rules. Based on the results of interviews with the head of the school during the initial observation, the preparation for the readiness of children to enter kindergarten has been done since the children were in the play group. And so far there have never been complaints from teachers or parents about children who have problems with children when they are in childhood so that researchers are interested in seeing how Kober is in preparing students to have school readiness.

\section{Review of Literature}

\subsection{Characteristics of Playgroup's Children}

Playgroup is a form of PAUD in the path of non-formal education that organizes educational programs as well as welfare programs for children aged 2-4 years. The aim of implementing family planning is to provide education, nutrition and child health services in a holistic manner and optimize child development according to the potential of children, which is carried out while playing. In more detail the goal is, first to increase confidence in religion, second in developing character in the life of the child. third, develop socialization and emotional sensitivity. Fourth, improve discipline through living habits. Fifth, develop communication in language skills. Sixth, improve knowledge or experience through thinking ability. Seventh, develop fine motor coordination and creativity in skills and art. Eighth, improve gross motor skills in physical health.

In about 3 years, a child begins to lose his form of kebayian and begins to embrace a slim and athletic form of childhood. As the abdominal muscles harden, the baby's distinctive tenderness begins to disappear. The body, arms, hands and feet grow longer. The head is still relatively large, but other parts of the body keep trying to follow along with the increasingly similar appearance of the body to the body of an adult. The development of muscles and bones (muscular and skeletal), makes children stronger. Cartilage becomes bone faster than before, and bones become harder and stronger, giving a child a more slender shape and protecting internal organs. These changes, which are coordinated by the maturity of the brain and nervous system, and along with developing the immune system, keeping children healthy (Papalia, 2008: 310-316).

\subsection{School Readiness}

Readiness or readiness is considered as a condition where someone has had the readiness to do something. According to Cronbach in Wasty Soewanto (1998: 191) provides an understanding of readiness as all the properties or strengths that make a person can react in certain ways. The development of readiness occurs by following certain principles, namely:

- All aspects of growth interact and together form readiness

- A person's experience influences the growth of individual physiology

- Experience has a cumulative effect in the development of individual personality functions, both physical and spiritual

- If the readiness to carry out certain activities is formed in a person, then certain moments in a person's life is a formative period for the development of his personality.

The following are 4 factors that parents must consider as explained by Drs. Bambang Sujiono, M.Pd, doctoral candidate for Early Age Education (PUD) at Jakarta State University. 


\section{a. Physical Readiness}

Physical aspects include gross and fine motor. In gross motoric, for example, children are able to move all their limbs to do movements such as running, climbing, up and down stairs, throwing a ball, even doing two movements at once such as jumping while throwing a ball.

Learning activities in kindergarten do rely heavily on gross motoric skills. Therefore, if children actively move, that is what is expected. Later in kindergarten other physical aspects are developed such as balance, flexibility, endurance and others. So do not let the child, for example, the strength of his legs be good but the balance is less so easy to fall. Or, just playing for a moment immediately tired. All physical aspects that become the motoric part of a child, then must be developed in kindergarten.

While fine motoric will be in line with the learning given in kindergarten. Children will learn to cut, fold, insert balls, choose seeds. Well, it will all work if supported by good physical.

\section{b. Emotional Readiness}

The most important emotional readiness concerns independence. At the very least, when the child is in class, he or she sits alone, does not depend on anyone, and is willing to follow orders. Another emotional readiness is indicated by the readiness of the child to accept the new situation. Of course it is only natural that in the first days, crying children face different situations from home. However, children who are more prepared, a few days later are able to mingle with their friends and are ready to receive guidance and learning.

They had no longer run in class when asked to sit by his teacher, only preparing children for socialization readiness. That is, if the child is not afraid to meet people, shows interest in friends, then he is ready. This must be prepared. But actually not only this. Children are not only not afraid of dealing with other people, but also want to listen to others. This ability is important in socializing and if the teacher speaks but the child runs here and there, the emotional stimulation he receives is incomplete. So, children must also be taught, how to become listeners before entering kindergarten.

\section{c. Cognitive Readiness}

One of them is language skills because in kindergarten children are expected to be able to understand the instructions given by the teacher. He was also expected to be able to express his opinions, feelings, and contents even though he was not yet coherent. Thus, children must also have sufficient vocabulary for their age.

What about read-write? This ability is not a requirement to enter TK. However, if the child is able to do so, it is recommended that parents find a suitable school for him. If the child already has the ability to calculate, for example, and he is put in a kindergarten where his children cannot even count 1 to 10, then the potential might be lost.

For children like this, of course special care is needed. That is, we may not generalize with other friends because of their different potential. So, we must really see the uniqueness of each child and it must be run individually.

Parents also don't expect that in their kindergarten their children will be taught to read and write and math like in elementary school. What is done in kindergarten is teaching children to know the basics and that is done through playing. For example, recognize letters, colors and numbers. 


\section{d. Social Readiness}

In kindergarten, children gather with friends who they have just met. He will try to adjust to the new school environment. He will also recognize the new rules of living together and listening to "lessons" from the teachers while studying with his friends.

Social readiness is seen from the child's ability to not be afraid of facing strangers, dare to enter a new environment and not hesitate to be invited to communicate. For example, there are children who have been in school for weeks still crying if left by their mother. This means the child is still afraid to be in a new environment. Different from those who are ready, usually they are happy when meeting new friends.

Cronbach's opinion means that school readiness is the strength or nature of a person in responding through certain ways. Readiness is also defined as being prepared and equipped to do, act immediately, or use something (Carol Seefeldt and Barbara Wasik A, 2002: 33). Children's readiness for school has a very important role because this will affect profits and progress in subsequent developments. According to Sorenson (1964) that readiness means good progress and get satisfactory results if a task or treatment is given (Sulistyaningsing, 2008: $10)$.

\subsection{Aspects of School Readiness}

The conditions for the child to enter school are physical conditions that are healthy and strong enough to do school assignments; there is a desire to learn; fantasy is no longer free; the development of social feelings is adequate (Zulkifli, 2005: 52). In addition, according to the morrison aspects of school readiness, there are six aspects of school readiness that need to be considered, namely language; independence; self control; interpersonal skills; physical health; mental and emotional; background of learning experience (Morrison, 2009: 270). Based on the opinion of Morrison above, it can be explained that aspects of language include children's language skills have reached the level according to their development, namely children are able to communicate and understand what is communicated by others. Children are also able to understand simple symbol symbols. The aspects of independence include self help, health skills (toilet training, washing hands, brushing teeth, and cleaning personal belongings in school), eating skills such as using tableware and napkins, taking meals by yourself and tidying up eating utensils after eating.

Meanwhile, according to Purwanto (2007: 136), children are said to be mature to go to school if they have physical and rokhani abilities to adjust to school livelihood:

a. The child has little awareness of his obligations and work. The child can be told to do other tasks assigned to him.

b. Children's interest has been directed to the outside world. This means that not only is he alone the center of attention, but also the events or circumstances outside him, his egocentric nature has gradually shifted towards straightforward nature.

c. The feeling of his intellect has developed. Children want to know something they don't know, like wanting to be able to write, read or count like their siblings or friends.

d. His social feelings have also developed. Children want to be friends more than their own family members. Children need a wider association, and each other serves the needs and wishes of other children, especially in joint games.

e. Also that should not be forgotten is that the growth of a child health agency is sufficient and able to carry out school tasks, for example strong children run, hold hunger and thirst and are not sick. 
So from the above description we can conclude that aspects of children's readiness to enter school consist of physical and psychological aspects. Physical aspects include physical health and motor skills, while psychological aspects refer to cognitive abilities, language skills and communication, independence, general knowledge, and children's social emotional development in accordance with the level of development of their age.

\subsection{Center in Kindergarten}

The center learning model was first discovered by Helen Parkhust who was famous as Dalton's plan or Dalton's school. In Soejono (1978: 120) states that this theory emerged after seeing the development of education in the United States developed by Maria Montessori has various disadvantages, among others:

a. children are too bound by how to complete work, because all learning tools must be used in a certain way.

b. In the Montessori system there is no social education for the common good, there is only individual education.

c. Ignoring the goodness of the classical system.

The latest development about learning models based on centers is the main characteristic of giving scaffolding to develop concepts of rules, ideas, and children's knowledge as well as concepts of density and intensity of play. This learning model is a learning approach that focuses on the central level which is centered on playing and when the child is in a circle. Sentra according to Isbell, children can form, feel, experiment, and be creative. Effective centers are designed by connecting the world of children and planning to support their involvement. Children usually have a sense of curiosity with the environment in which they live, the center is a symbolic representation into their world. In this center they can try to share ideas and repeat events according to the stages of understanding their knowledge. In this environment, they can build self-confidence and begin to trust their learning abilities. In the center of small groups of children can work together, more likely than larger groups. Children can work together when they feel close while responding, communicating and working (Rebecca Isbell, 1995, 17).

According to Isabell, there are generally eight centers that have been used for years, namely:

a. Household Centers

This center is a perfect transition between home and school. Younger children are very familiar with the roles and objects used at home. Children can play adults, children, or babies who are crying. In such an environment they can express their ideas and experiment with the tools available. Often times children who are not confident can build their confidence when they play at home. The purpose of playing here is 1) to expand their spoken language when they talk about activities that occur 2) to develop a positive view of their abilities because they dramatize familiar events 3 ) to begin to understand others, and learn about their needs and responsibilities.

\section{b. Sentok Balok}

Beam play can improve children's development physically, socially and intellectually. The beam center covers many types of building objects for children's use in construction and combines them. Sentra is designed so that children can actively build blocks according to what they think, discuss and dramatize the functions of their projects. The purpose of these beam centers is to: a) solve problems because they build with blocks. b) to expand the 
language of their expressions when they are about building. c) to learn to work together and accept other people's work. d) to organize their world using symbolic representation in the play block.

\section{c. Art Center}

Children are generally very creative and enjoy art objects in experimenting with their ideas. By experimenting using different media, they begin to understand their world and how to control the equipment they use. In the early years the process of creating was more important than the results of child development. Art centers should be a place where children can enjoy artistic creations and get support when they start working. The purpose of learning at the arts center is a) to be more creative when they participate in art activities. b) to understand their world as they experiment with different materials and tools. c) to learn about art and illustration. d) to build children's confidence when they make decisions and implement their ideas.

d. Playing water and sand is very important for children. these natural objects encourage children to explore and experiment with something they learn. When children interact with these objects, they refine coordination and experiment with using the tools they use. Children's interest in water and sand makes these centers effective for increasing the time period their attention involves them in activities. The learning objectives of this center are about natural elements in the environment; to develop small motor coordination because they manipulate materials and tools; to have the opportunity to experiment with materials that are immediately responsive to their actions; to use problem solving like they explore.

\section{e. Library Center}

This center is the most important center for early childhood. This place is designed in such a way that children have an interest in reading and enjoying the stories of the stories that are held here. In children's library centers can design images and capture their interest in books and related objects. The purpose of playing Disentra is to develop their interest in various books, magazines and other printed materials, to learn that stories can be in various forms including books, magazines, tapes, stories and show flannel dolls to enjoy reading books and recounting them.

\section{f. Sound and music centers}

Basically children are attracted to sounds and music and which begin when babies are up to childhood. music inspired them to be happy. The art center is an environment where children will experiment with sound while creating their own music. The aim of playing this dysentery is to enjoy making music and participating in music activities, to explore sounds produced by different objects and instruments to listen to various music, to improve their self-concept as they learn new ways to express their feelings.

\section{g. Sentra writes}

This center is a place where children can communicate in writing. Children love writing and often read what they write. The purpose of playing this dysentery is to encourage them to communicate their ideas in written form, to appreciate the writings of others, to learn about computers and how they can be used in writing. 


\section{h. Center for natural science}

Children are very interested in everything in their environment. Questions that encourage the centers of natural science can make children become little researchers, study the objects they find or explore findings that are their attraction. In this center children will learn about comparing, observing, seeing differences and making conclusions from what they see. The purpose of learning in this area is to learn about nature, for experiments and their ideas to develop problem solving and question skills and for value methods and use scientific inquiry.

From the above description it can be understood that the center learning model has various types of centers that can be used to develop the ability of children aged 2-4 years. Each center has different objectives and is adjusted to the needs and development of children in the play group. Central procurement is flexible, does not have to always be the same as the center procurement standards so that it can be reduced or held in accordance with the needs and objectives of institutions that will use the center learning model.

\section{Research Method}

This study uses a qualitative method that refers to the natural paradigm that is derived from a phenomenological view, especially in relation to school readiness of children aged KOBER. The selection of qualitative methods was chosen because it is in line with what was conveyed by Nusa Putra (2012) which states that if you want to understand the learning process and everything about PAUD, the most suitable approach is qualitative research (Nusa Putra, 2012: 63). This qualitative research researchers conducted observations, interviews and psychological testing to obtain the truth of empirical data. So according to Moeleong (2000: 3 ), it will produce descriptive data in the form of written or oral words from people or observable behavior. Through the collected empirical data it is believed that it will be able to answer the problems in this study.

This research was conducted in the play group of the sub-village mother of the toddler village, based on the center learning model. When this research was conducted since November 2015 as the researchers' initial observations, it was then resumed again during the second semester of the school year, which was around February and March 2016 until April 2016, precisely when the children entered the second semester.

This research was conducted in a play group of mothers of toddlers in the village of Kertajati Sub-District, Kertajati Majalengka, West Java Province. With the focus of the study is the children of October and how the efforts made by the teacher to help develop the school readiness of children ages 2-4 years old. The background in this study were teachers and children of October in the second semester. This study is more focused on children because children are the main figure who will later pass the transition from October to kindergarten / RA is a time that is not easy for children so that in this case need special attention.

According to Emzir (2010: 37) in more general sources of data collection are observations, interviews, and documents that are sometimes also used together and sometimes individually. So that in an effort to get the data needed in this study the teachers were playing groups of 2 people as well as 10 children. the data that will later be produced in this study are

a. The results of a child's psychology test as a document used to create a profile of a child's school readiness

b. Data obtained from interviews and observations to teachers when activities are stopped. 
The results of data collection that is still in the form of rough data will then be reprocessed according to the data analysis procedure so that the data obtained will be more meaningful (Miles humberman, 1984: 10). So that it can explain how children's school readiness, as well as stimulation given by the teacher when learning is stopped. Data obtained from the NST test results in the form of numbers are then converted into narratives. This is the main and important thing. Numbers are in accordance with what was conveyed by Nusa Putra (2012: 06) that qualitative research is not absolutely rejecting numbers and calculations, but numbers and calculations are used very limited and have never been the main and important ones. Numbers and calculations are used if indeed they can help understanding and explanation. But it remains in a qualitative framework.

\section{Discussion}

Based on the results of the test using NST, it was found that KOBER children of mothers of toddlers were aware of having had school readiness, only that it seemed lacking was how children interpreted a story in the form of images that still tended to be lacking. This is in line with learning, when the teacher tells the story, it appears that stimulation given by the hut in verbal form, such as discussion and question and answer about the story just read by the teacher can be seen in the graph below:

From the questions filled by the homeroom teacher, it appears that the child's ability is that the ability of children in terms of social adjustment is quite good, the ability to solve tasks, and independence are quite good in the daily activities of children to be tasked with focusing and completing tasks. So that it goes into the school ready category. Learning activities are not separated from the teacher as a mediator, motivator, facilitator and child evaluator in playing in the center. Based on the observations of the researchers, the teacher's preparation in teaching was neatly prepared. There is a central coordinator who often holds meetings to discuss learning about disentra. In addition, teaching activities cannot be separated from the Term Fact And Principles, as a basis for teaching which was later developed into a lesson plan. By applying the motto does not scold the child, does not tell the child and does not prohibit the child, makes the child free to express in accordance with the ability and development potential of the child but still in the control and supervision of the teacher.

Stimulation of children's physical and motoric activities during learning activities in the form of: Writing exercises, Playing puzzles Playing blocks Meronce Sticking Arranging letters Arranging pests Building blocks Arranging tracing geometry shapes sticking to Finger Painting Painting Playing sand Beat soap Painting. Psychological aspects are very important aspects for the readiness of school children. Psychological aspects here refer to cognitive abilities and general knowledge, children's language and communication skills, independence, and social emotional through play activities since morning, when welcome to school, morning journal, pledge, circle time I, free play, morning snack, play stopped, lunch, dhuhur prayer until noon the child comes home from school.

\section{Conclusion}

Based on the discussion of the results of the data analysis and discussion, the conclusion of this study is based on the results of the NST test, the play group children have had school readiness. The readiness of this school is achieved because the average level of education of 
teachers is sufficient to understand the development of children and understand how to prepare children to be able to enter the next level of education. Good teacher preparation before teaching, supported by facilities and infrastructure as well as playground equipment that is quite complete so that it supports center learning activities adapted from the BCCT approach but modified with school conditions, where the morning activities begin with morning journal activities.

The form of stimulation given by the teacher for the readiness of school children, in accordance with the physical motor aspects, cognitive and language, social emotional, and independence, as follows: stimulation is given since the morning, namely from the child to school through activities welcome to school children are taught to say hello and communicate well; The stimulation can take the form of exemplary, habits, and through learning activities being stopped; Learning activities are arranged according to the themes developed in the lesson plan. Activity is integrated between one and the other to stimulate children in physical, cognitive and language aspects, emotional social, independence, through various kinds of play activities such as free play, providing opportunities for children to cooperate, giving children the opportunity to make their own decisions, giving children the opportunity to become leaders, the opportunity to choose the type of game they like, returning the playground to its place, going wrong, talking well reading stories, the base puzzle is there arranging letters, pests, geometric shapes, macaroni letters, syllable cards , reading poetry, plagiarizing, coloring and cutting and also drawing, sticking, folding, playing play dough, pinger painting, painting, singing, copying, drawing freely, and printing, stamping, pinger painting, painting large brushes or small brushes, playing sand, shake soap, waterwheel, pour and fill water, water pumps, fishing, paint walls, cut, teaches how to perform ablution, how to pray, and the introduction of hijayyah letters and numbers to write Arabic letters, write arabic numbers, recite, toy flannel, read story books, miniature beams of places of worship, role playing and playing temple.

\section{References}

Chaedar Alwasilah, pokoknya kualitatif, Bandung: Kiblat Buku Utama, 2003 Jalal, Fasli, The material presented at the National Level Technical Orientation event at Saphir Hotel Jogjakarta, November 7, 2011

Emzir. Metodologi Penelitian Kualitatif: ANALISIS DATA, Jakarta: Rajawali Pers, 2010

Fridani, Lara, APE Lesatri, PAUD Pendidikan Anak Usia Dini, Jakarta: Gramedia, 2009

George S Morrison, Early Childhood Education Today, New Jersey: Pearson education, 2009) Herdiansyah, Haris, Metodologi Penelitian Kualitatif Untuk Ilmu Ilmu Sosial,, Jakarta: Salemba Humanika, 2010

Kathy Charner, MaureenMurphy, Jennifer ford, Brain Power Berbasis Sentra Pembelajaran, Jakarta: Erlangga, 2005

Miles, Matew B, A Michael Huberman, Analisis Data Kualitatif, Jakarta terjemahan Tjetjep Rohendi rohidi Universitas Indonesia, 1992

Moleon, Lexy, Metodologi Penelitian Kualitatif, Bandung: Remaja Rosdakarya, 2010

Morrison, George , Fundamentals Of early Chilhood Education, 5 th Ed. Terjemehan Suci

Ramdhona, Apri Widistuti, Jakarta: Indeks, 2008

Muti, Diana, Psikologi Bermain Anak Usia Dini, Jakarta: Kencana, 2010 
Nusa Putra, Ninin Dwi Lestari, Penelitian Kualitatif PAUD, Jakarta: PT Raja Grafindo Persada, 2012

Papalia, Diane E, Human Development, edisi Kesembilan, terjemahan: A.K Anwar., Jakarta: Prenada Group, 2008

Pamela Coughlin, Kristen A hansen, Dinah Heller etc, Creating Child Centerede Classrooms, washington, Children's Resource Internasional, 2000

Purwanto, Ngalim, Ilmu Pendidikan Teoritis dan Praktis, cet ke 18, bandung: Remaja Rosdakarya, 2007

Richaerd C Woolfson, Why Do Kids Do That Jakarta : erlangga, 2005

Rusdinal dan Elizar, Pengelolaan Kelas Taman Kanak Kanak, Jakarta: Dikti, 2005

Santrock, john W, Perkembangan Anak, Jilid 1, terjemahan Mila Rachmawati, Anna Kusumawati, Jakarta: Erlangga, 2007

Sujiono, Yuliani Nurani, Konsep Dasar Pendidikan Anak Usia Dini, Jakarta: Indeks, 2009

Yamin, Martinis, Jamilah Sabri Sanan, 2010, Panduan Pendidikan Anak Usiaa dini, Jakarta: Gaung Persada Press, 2010

Yulianti, Dwi, Bermain Sambil Belajar Science, Jakarta: Indeks, 2010 